\title{
Conversations with Celebrity Authors
}

Like most assistant professors, I had to write a book in order to get tenure, but I didn't really expect anyone to read it. However, its topic-literary celebrity in the United States-seems to have generated a peculiar effect: over the years since its publication I've been receiving letters from a variety of well-known writers commenting on their absence from its pages.

The first letter was from my father's old college buddy, Philip Roth. Here's what he had to say:

\section{Dear Loren:}

Some time ago your father sent me a copy of your book. I was busy with The Plot Against America at the time, and my assistant put it in the rather large pile of literary criticism that I receive on a weekly basis. This pile tends to be low priority for me. However, I occasionally take a certain pride in the scale, if not the substance, of the academic attention I receive, and last month I was idly attempting to estimate the height of the pile (somewhere between a short adult and a tall child, happily bringing to mind the adolescent puerility of so much of it), when I noticed your title.

Now, Loren, in the rare instance that I pick up a book by one of your breed, I glance through the index first to ensure that I am adequately represented in relation to whatever subject is being squeezed of all interest by that peculiar enemy of literary appreciation known as the American English Department. Imagine my chagrin, then, when I could derive no narcissistic pleasure from the empty space between "Mark Rose" and "John Carlos Rowe" (who are they, anyway?); this in a book on celebrity authorship, written by one of the few young scholars in whose career I maintain a passing interest.

Aside from the personal affront, this seems a galling gap in your argument. Certainly few twentieth-century authors have focused more resolutely and even ostentatiously on their own celebrity. Since rocketing into the mass media stratosphere with Portnoy's Complaint, I've been inventing autobiographical avatars, including myself, in order to meditate upon and manage the cultural consequences of 
my fame. It would indeed not be an exaggeration to say that my entire career of self-reflexive speculative autobiographical fiction has been elaborately constructed as a response to both the attacks and the accolades I received for that book. Surely I am the postmodern celebrity author par excellence. This couldn't possibly have been an oversight. Might it be some sort of displaced oedipal animus?

Best,

Uncle Phil

PS: Did you read the New York Times Book Review of May 21, 2006?

I replied:

Dear Uncle Phil:

Can I be blunt? I didn't want to deal with the whole Jewish thing. True, I have a chapter on Norman, but he downplayed his ethnic origins, indeed felt that his fame had erased them. This made him a somewhat "purer" example of the phenomenon I wanted to trace. If I were to have written a chapter on you, I would have been constantly deflected by Jewishness, both in the thematic obsessions of your work, and in the constitution of your audience. I acknowledge that, in your more recent novels, this focus has diminished somewhat, but dare I say that this diminishment has been accompanied by a dwindling of your popularity? To the degree that you were famous in the sense that would have been relevant for my book, you were famous as a masturbating Jewish boy obsessed with shiksas.

Let's face it, Phil. You're not that famous anymore. I of course read A.O. Scott's NYTBR article, and I congratulate you on your triumph therein, but this middlebrow apotheosis only confirms your increasing irrelevance as a public figure on a mass cultural scale. It must be a relief.

Anyway, how can you expect me to write about a man who was at my bar mitzvah?

Cheers,

Loren

The next author I heard from was Bret Easton Ellis, whom I'd met briefly at a Dress-to-Get-Laid Party at Bennington College. He was wearing an Armani suit and a pair of Vuarnets; I was wearing a tutu. I didn't get laid that night. 
Bret sent me a postcard, one of those promotional deals you find in a rack by the bathroom at a big city nightclub. This one appeared to be for some sort of soft-core men's magazine, but it was hard to tell for sure. Bret got right to the point, scrawling in red ink:

Loren,

Where the fuck am I in your fucking book? I gave you a fucking cameo in The Rules of Attraction. The least you could do is fucking return the favor.

Fuck You,

Bret

PS: your Amazon.com rank: 1,629,489; my (latest) Amazon.com rank: 7,087

I sent Bret a postcard with a picture of Marilyn Monroe:

Dear Bret,

You're not as fucking famous as you think.

Fuck You,

Loren

PS: your highest academic degree: BA; my highest academic degree: $\mathrm{PhD}$

The very next day I got a package from David Foster Wallace, from whom I had taken tennis lessons when I was an undergrad English major at the University of Massachusetts, Boston, and he was a high school student teaching tennis to finance his marijuana habit. Inside was a 4,00o-page typescript entitled "My Celebrity," which he claimed to have written the night before while on an oral cocktail of Vinyl Caprolactam, Dimethylaminoethyl Methacrylate Copolymer, Caprylic Triglyceride, Amodimethicone, Benzophenone4, Trideceth-10, Myreth-3 Myristate, and Limonene. ${ }^{1}$

1. When combined with water and fragrance, this potent psychotropic combination is manufactured as hair styling crème by Bumble and Bumble, London and New York, patent pending. Its utility as a central nervous system stimulant was discovered by a gang of lesbian skatepunks in South Boston who needed to stay up all night embroidering insignia for an underground fashion show in Provincetown. Its enhancement of digital dexterity is particularly notable. See Jakov Wakov, DDS, AACS, "The Effects of Synthetically Dehydrated Bumble and Bumble Styling Crème on the Typing Speed of Borderline Personalities," East Anglian Journal of Over-the-Counter Psychotropics il (June 2005), $135-79$. 
I haven't gotten around to reading it, but I'm keeping it as a monument to his memory.

Then I received a missive from Toni Morrison, with whom I had dined some years ago during her visit to my university. Our brief exchange consisted in my saying, "I loved your talk," and her answering, "Thank you."

\section{Dear Prof. Glass:}

I wouldn't have read your book had it not been brought to my attention by one of my many good friends in your field of American literary and cultural studies. She brought it to my attention not because the topic would interest me-it doesn't, really-but because of the absence of women of color. You discuss one female author-Gertrude Stein-and no African-American authors. Thus your study neglects an entire tradition-from Hurston to Walker, from Wright to Baldwin-important authors who, in addition to establishing the central roles of race and gender in the American literary imagination, grappled heroically with the issues you discuss in your book. It saddens me to see that, after all the progress we've made in expanding the canon of American literature, white men continue to write books about other white men.

Sincerely,

Toni Morrison

PS: I recommend you read A.O. Scott's article in the New York Times Book Review of May 21, 2006.

\section{Dear Ms. Morrison:}

Actually, I considered starting my book with Frederick Douglass. Certainly one strand of the phenomenon I analyze can be traced to the African-American experience. My plan was to establish the slave narrative as one of the first American genres to define the modern split between private and public selves, and to offer Douglass as one of the first figures to experience the disorientation of having an entire industry concerned with the manufacture and circulation of a specifically literary celebrity persona. But in the end I decided that this topic was too large to be subordinated to my central focus, and rather would deserve a separate booklength study (a study which I would welcome). 
As for your own career, which you reference only obliquely, I suggest that it is, in a sense, to your credit that you don't fit that well into my stated topic. You have guarded your private life quite effectively, and the popular press has been relatively unconcerned with it. Based on my readings of many Hemingway biographies, I think you can consider yourself lucky.

Sincerely,

Loren Glass

Assistant Professor of Literary and Cultural Studies

Then I heard from Jonathan Lethem, who once sold me a used copy of Norman Mailer's Advertisements for Myself when he was a clerk at Pegasus Books in Berkeley. When I got home, I realized he had signed it under the scrawled comment: "Dear Loren, one day this will be worth a lot of money."

\section{Dear Loren:}

I aspire to be in your book. Actually, I note by the copyright date that you most likely had finished writing before the publication of The Fortress of Solitude, so you probably hadn't realized what a big deal I've become. Now you know. Indeed, you probably also know that there are a number of graduate students in your department writing dissertations on me; so, based on your own calculus, you'll need to add a coda on me if it ever gets reissued.

Sincerely,

Jonathan

PS: Do you still have that copy of Advertisements for Myself?

Dear Jonathan:

Truth to tell, I prefer to write about dead people. I realize that Mailer is still alive, but that's only biologically speaking; for all intents and purposes, his career was over long ago. If it's any comfort, I see you as a far better novelist, if a less notorious public figure. My book is unlikely to get reissued, but if it is I promise to mention you.

Cheers,

Loren

PS: It's in my safety deposit box. 
A few days later, I received a brief letter from Jonathan Franzen, who had snubbed me the week before at a reception following his reading at Prairie Lights Bookstore.

Dear Professor Glass:

I can't tell you how gratified I am not to appear in your book. As far as I'm concerned, such puerile cult-stud tripe is simply an academic symptom of our attention-deficient, pornographyobsessed, profit-driven, banalized, commodified, technologized Oprah-culture. I dream of a day when novels are read intelligently and novelists are left alone.

I left him alone.

Finally, I received a cryptic e-mail from Thomas Pynchon, with whom I once got stoned at an undisclosed location in Northern California (and who receives a single reference on p. 198 of my book): "I am not in your book."

I didn't answer. 